\title{
Serological Evidences of West Nile Virus in Domestic Bird Species in the Samsun Province
}

\author{
Sinan Pir ${ }^{1}$, Harun Albayrak ${ }^{2 *}$ \\ ${ }^{1}$ Department of Poultry Disease, Veterinary Control Institute, 55400, Samsun, Turkey (Corresponding Author) \\ ${ }^{2}$ Department of Virology, Faculty of Veterinary Medicine, Ondokuz Mayis University, Atakum, Samsun, Turkey
}

Geliş Tarihi / Received: 13.10.2017, Kabul Tarihi / Accepted: 10.11.2017

\section{Serological Evidences of West Nile Virus in Domestic Bird Species in the Samsun Province}

\begin{abstract}
West Nile fever (WNF) is a zoonotic disease, occurring nearly globally. Birds are important host species of West nile virus. West nile virus (WNV) is a mosquito-borne viral disease. Although West Nile Virus causes an asymptomatic infection, especially it can cause neurologic disorders in humans, birds and horses. In this study, blood samples were randomly collected from domestic birds (chicken, duck, goose and turkey). The material consisted of 736 domestic birds, including 394 geese, 129 ducks, 117 turkeys and 96 chickens, from Samsun province in northern Turkey. The serum samples were analysed for the presence of antibodies to WNV using a competitive enzyme-linked immunosorbent assay (C-ELISA). Seropositivity rates in chickens, ducks, geese and turkeys were detected as $3.1 \%, 0.8 \%, 1.8 \%$ and $17.9 \%$ for WNV. Out of 736 serum samples examined, $32(4.3 \%)$ were positive for WNV. The results, recorded for the first time for WNV in Turkey, supported the hypothesis that domestic bird act as a potential reservoir of WNV, and thus have a role in the epidemiology of these diseases.
\end{abstract}

Keywords: Domestic birds, ELISA, Turkey, West Nile virus.

\section{Samsun İlindeki Evcil Kanatlı Türlerinde Batı Nil Virusunun Serolojik Bulguları}

Özet: Batı Nil ateşi hemen hemen küresel düzeyde görülen zoonotik bir hastalıktır. Kuşlar batı nil virusunun önemli konakçılarıdır. Batı nil virüsü (BNV) sineklerle taşınan bir virüstür. Batı Nil virüsü asemptomatik bir enfeksiyona sebep olmasına rağmen, özellikle at, kuş ve insanlarda nörolojik bozukluklara neden olur. Bu çalışmada, evcil kanatlı türlerinden(tavuk, ördek, kaz ve hindi) rastgele örnekleme yoluyla kan örnekleri topland. Samsun ilinde 96 tavuk, 117 hindi, 129 ördek ve 394 kaz olmak üzere toplam 736 kanatlı kan serum örneği toplandı. Serum örnekleri c-ELISA metodu kullanılarak Batı nil virusu antikorları yönünden test edildi. Seropozitiflik oranı Batı Nil virüsü için tavuklarda \%3,1, ördeklerde $\% 0,8$, kazlarda $\% 1,8$ ve hindilerde $\% 17,9$ olarak tespit edildi. Toplamda 736 serum örneğinin 32'si (\%4,3) Batı nil virusu antikorları yönünden pozitif bulundu. Sonuçlar, Türkiye'de evcil kanatlılarda Batı Nil virusu için ilk veriler olup, kuşların BNV yönünden potansiyel rezervuar olduğu ve hastalıkların epidemiyolojisinde önemli bir role sahip olduğu hipotezini desteklemektedir.

Anahtar kelimeler: Bat1 Nil virüsü, ELISA, Evcil kuşlar, Türkiye.

\section{Introduction}

Domestic birds are important to public health because they can be infected by a number of pathogenic microorganisms that are transmissible to humans. Among the most important of these diseases are emerging infectious diseases that are newly recognized or previously known diseases that appear in a new population or are rapidly increasing in incidence or geographical area.

West Nile virus has a wide geographical range that includes portions of Europe, Asia, Africa,
Australia (Kunjin virus) and North America [4,14]. West Nile virus (WNV), genus Flavivirus, family Flaviviridae, is an "old-world" arbovirus, transmitted mainly by infected mosquitoes. Wild birds are the primary amplifying hosts of the virus, but a number of species (amphibians, domestic poultry, and mammals, including humans and horses) can be infected through bites from WNV-infected mosquitoes, and disease will develop in some $[11,14]$. The diagnosis of WNV infection is commonly achieved using serological assays. While plaque reduction neutralization tests are still considered the gold stan-

* This study was summarized from the MSc thesis of first author.

Yazışma adresi / Correspondence: Sinan Pir, Department of Poultry Disease, Veterinary Control Institute, Samsun, Turkey

E-posta: sinanpir@gmail.com 
dard for specific diagnosis, ELISA is now routinely used [5], as it is less laborious and more suited to high-throughput screening. WNV infection and antibodies have been detected in humans and animals in Turkey $[10,19]$.

The objective of this study was to perform serological investigation of $\mathrm{WNV}$ in domestic birds (chicken, duck, goose and turkey) reared in rural areas of the northern Turkey.

\section{Materials and Methods}

\section{Ethical Committee Approval}

The study protocols and experimental procedures were approved by the Samsun Veterinary Control Institute Scientific Ethics Committee (No: 20).

\section{Sample collection and processing}

Blood samples were randomly collected from domestic birds, including 394 geese (Anser anser), 129 ducks (Anas platyrhynchos domesticus), 117 turkeys (Melagris gallopavo) and 96 chickens (Gallus gallus domesticus), without clinical signs of the diseases from Samsun province and their towns (Bafra, Kavak, Ladik, 19 Mayis and Terme) in the northern part of Turkey between January and May 2013 (Figure 1.). The age of the animals varied from 11 months to 9 years. Blood samples were taken from the wing veins of the birds. Blood tubes were centrifuged at $3,000 \times \mathrm{g}$ for $10 \mathrm{~min}$, and sera were transferred to sterile tubes and stored at $-20^{\circ} \mathrm{C}$ until investigation.

\section{ELISA (Enzyme Linked Immunosorbent Assay)}

The commercial ELISA kits were obtained from ID.VET, Montpellier, France, and the tests were performed according to the producer's description. This diagnostic kit is designed to detect avian IgG antibodies directed against the West Nile Virus envelope protein (pr-E) by competetive ELISA. Plates were read with an ELISA reader at $450 \mathrm{~nm}$ and results were calculated.

\section{Statistical Method}

The chi-square test was used to determine the significance of obtained results.

\section{Results}

A total of 736 serum samples (chicken, duck, goose and turkey) were examined for antibodies against WNV as detailed in Table 1. The overall seroprevalence was found to be $4.3 \%$ (32/736) for WNV.

No anti-WNV antibodies were detected in all domestic birds in Bafra, Kavak and Ladik towns. Seropositivity rates in chicken, duck, goose and turkey were detected as $3.1 \%, 0.8 \%, 1.8 \%$ and $17.9 \%$ for WNV. The provincial distribution of WNV seroprevalence in this study was as follows: 19 Mayis $23.1 \%$ and Terme $4.1 \%$. The highest rate of seropositivity (27.3\%) was detected in 19 May1s town of Samsun province from turkey for WNV. The turkey was more susceptible for WNV infection than other domestic birds (chicken, duck and goose) $(\mathrm{p}<0.01)$.

\section{Discussion and Conclusion}

West Nile virus has a wide geographical range that includes portions of Europe, Asia, Africa, Australia and America [14]. Many serological test methods were used in the diagnosis of WNV such as plaque reduction neutralization test (PRNT) and ELISA. While PRNT is still considered the gold standard for specific diagnosis, ELISA is now routinely used [6]. The C-ELISA has a higher specificity $(99.4 \%)$ and sensitivity (84.9\%) for WNV infection [16].

West Nile virus has not affected commercial chickens (Gallusgallus domesticus) or turkeys (Meleagridis gallopavo), which are predominantly raised indoors with low potential for exposure to mosquito vectors [13]. However, natural WN virus infections were associated with severe neurologic signs and death in 8- to 10 -week-old domestic geese from a flock in Israel [12]. The role of domestic geese as a WN virus reservoir in the Israel outbreak is unknown, but goose infection rates in the Sindbis District of the northern Nile Valley were $27 \%$, suggesting that geese may have a role in local WN virus ecology [17]. West Nile virus antibodies have been detected in humans and animals in Turkey Albayrak and Ozan [2], Ergunay et al. [8], Ozkul et al. [15] and antibodies and viruses have been detected among mammals and vectors in the neighbouring countries of Balkan peninsula [11]. In addition, mosquito species known to transmit mos- 
quito-borne diseases have been observed in Turkey [6]. Ozkul et al. [15] carried out a serological survey in mammalian species. Positivity rates for the animals varied and were as follows: ass-mules $2.5 \%$; cattle $4 \%$; dogs $37.7 \%$; horses $13.5 \%$; sheep $1 \%$ and humans $20.4 \%$. There is no study on the seroprevalence of WNV infection in domestic birds in Turkey. The determined positivity in domestic birds in this study $(4.3 \%)$ was found to be very low comparing to the reported value in dogs, humans and horses.

Table 1. The number and ratio of WNV seropositive birds

\begin{tabular}{ccccccccccc}
\hline \multirow{2}{*}{ City } & \multicolumn{4}{c}{ Total number of animals } & \multicolumn{5}{c}{ Positivity (\%) (for WNV) } \\
\cline { 2 - 11 } & Chicken & Duck & Goose & Turkey & Total & Chicken & Duck & Goose & Turkey & Total \\
\hline Bafra & 24 & 26 & - & - & 50 & $0(-)$ & $0(-)$ & - & - & $0(-)$ \\
Kavak & 4 & - & 175 & - & 179 & $0(-)$ & - & $0(-)$ & - & $0(-)$ \\
Ladik & 12 & 38 & 118 & 40 & 208 & $0(-)$ & $0(-)$ & $0(-)$ & $0(-)$ & $0(-)$ \\
19 Mayis & 27 & - & - & 77 & 104 & $3(11.1)$ & - & - & $21(27.3)$ & $24(23.1)$ \\
Terme & 29 & 65 & 101 & - & 195 & $0(-)$ & $1(1.5)$ & $7(6.9)$ & - & $8(4.1)$ \\
Samsun (Total) & 96 & 129 & 394 & 117 & 736 & $3(3.1)$ & $1(0.8)$ & $7(1.8)$ & $21(17.9)$ & $32(4.3)$ \\
\hline
\end{tabular}

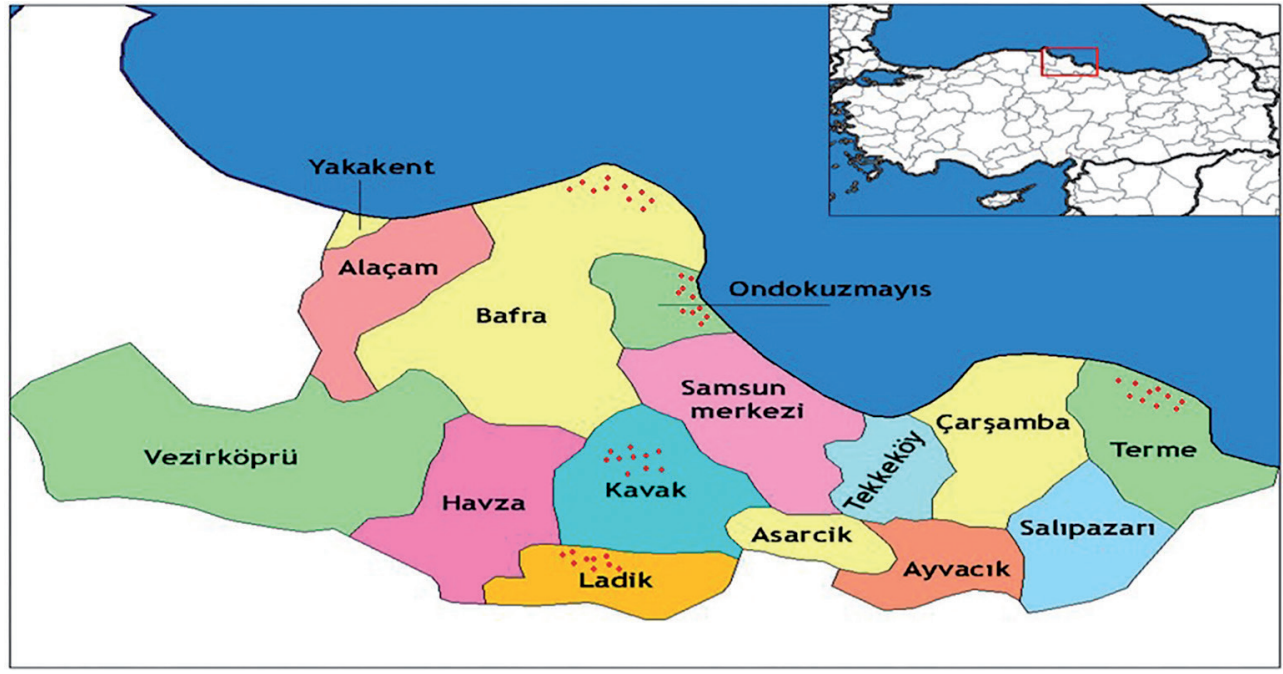

Figure 1. The map of the locations where samples were collected for serological assay

Albayrak and Ozan [2] carried out a serological survey in mammalian species.

Although they did not detected any WNV antibodies from cattle, horse, sheep and water buffalo samples, out of 70 goats, $2(2.85 \%)$ were found to be seropositive for WNV. Yazici et al. [20] studied a molecular study about presence of WNV in horse blood samples in the Ardahan province of Southern Turkey, but they did not detect any WNV nucleic acid from these samples. Albayrak and Ozan [1] performed a molecular study about presence of WNV in wild bird samples in the same region, although they did not detect any WNV nucleic acid from these samples, in this study, seroprevalence of WNV in domestic birds (chicken and tur- key) were most intense (23.1\%) in 19 Mayis town of Samsun. In this town there is a delta of a river called Kizilirmak, diverse avian hosts from Asia, Europe and Africa overlap in a region of intercontinental avifaunal mixing hypothesized to be an important zone of Europe- Asia-Africa virus transfer. Non-migratory birds become infected when WNVinfected mosquitoes feed on them. Evidence that the virus is transmitted between resident and migratory birds by infected mosquitoes can be obtained by detecting WNV-specific antibody, infectious virus or RNA in the non-migratory birds or in nearby animals.

It is commonplace knowledge that the result of the seroprevalance studies are influenced by many 
factors such as the number of sampled animals, the age of the animals, the time of sampling, the conditions of care and feeding, individual differences.

It was concluded that, the results, recorded for the first time for WNV in domestic birds in Turkey, supported the hypothesis that domestic bird act as a potential reservoir of $\mathrm{WNV}$, and thus have a role in the epidemiology of these diseases. To understand better acute infection rates of WNV in domestic bir$\mathrm{ds}$, additional studies focusing on field observations are needed.

\section{Acknowledgements}

Funding for this research was provided by the Ondokuz Mayis University Scientific Research Council (Project Number: PYO.VET. 1904. 13.002)

\section{References}

1. Albayrak H., Ozan E., 2010. Molecular detection of avian influenza virus but not West Nile virus in wild birds in northern Turkey. Zoonoses Public Health, 57, e71-e75.

2. Albayrak H., Ozan E., 2013. Seroepidemiological study of West Nile virus and Rift Valley fever virus in some of mammalian species (Herbivores) in northern Turkey. J Arthropod-Borne Dis, 7, 90-93.

3. Bagheri M., Terenius O., Oshaghi MA., Motazakker M., Asgari S., Dabiri F., Vatandoost H., Mohammadi BM., Chavshin AR., 2015. West Nile virus in mosquitoes of Iranian Wetlands. Vector-Borne Zoonot Dis, 15, 750-754.

4. Burke DS., Monath TP., 2001. Flaviviruses. In "Fields Virology”, Eds., DM Knipe, PM Howley, 4th ed., 10431126, Lippincott Williams \& Wilkins, Philadelphia.

5. Dauphin G., Zientara S., 2007. West Nile virus: recent trends in diagnosis and vaccine development. Vaccine, 25, 55635576.

6. Dik B., Yagc1 S., Linton YM., 2006. A review of species diversity and distribution of Culicoides Latreille, 1809 (Diptera: Ceratopogonidae) in Turkey. J Nat Hist, 40, 1947-1967.

7. Ergunay K., Saygan MB., Aydogan S., Menemenlioglu D., Turan HM., Ozkul A., Us D., 2007a. West Nile virus seroprevalance in blood donors from central Anatolia, Turkey. Vector Borne Zoonot Dis, 7, 157-161.

8. Ergunay K., Ozer N., Us D., Ozkul A., Simsek F., Kaynas S., Ustacelebi S., 2007b Seroprevalance of West Nile virus and tick-borne encephalitis virus in southeastern Turkey: First evidence for tick-borne encephalitis virus infections. Vector Borne Zoonot Dis, 10, 771-775.

9. Ergunay K., Bakonyi T., Nowotny N., Ozkul A., 2015. Close relationship between West Nile virus from Turkey and lineage 1 strain from Central African Republic. Emerg Infect Dis, 21, 352-355.

10. Gazi H., Özkütük N., Ecemis T., Atasoylu G., Köroglu G., Kurutepe S., Horasan GD., 2016. Seroprevalence of west nile virus, crimean-congo hemorrhagic fever virus, Francisella tularensis and Borrelia burgdorferi in rural population of manisa, western Turkey. J Vector Borne Dis, 53, 112-117.

11. Hubalek Z., Halouzka J., 1999. West Nile fever-a reemerging mosquito-borne viral disease in Europe. Emerg Infect Dis, 5, 643-650.

12. OIE, 1999. Office International des Epizooties. West Nile fever in Israel in geese. Disease Information, 12, 166

13. OIE, 2000. Office International des Epizooties. West Nile fever in the United States of America: in horses. Disease Information, 13, 150-151

14. OIE, 2015. The World Organisation for Animal Health. West Nile fever. Manual of Diagnostic Tests and Vaccines for Terrestrial Animals 2013. Volume 1, Part 2

15. Ozkul A., Yıldırım Y., Pinar D., Akcali A., Yilmaz V., Colak D., 2006. Serological evidence of West Nile virus (WNV) in mammalian species in Turkey. Epidemiol Infect, 134, 826-829.

16. Padilla JA., Rubio EL., Romero EE., Cordoba L., Cuevas S., Mejia F., Calderon R., Milian F., Rosa ATD., Weaver SC., Franco JGE., Saiz JC., 2009. The continous spread of west nile virus (WNV): seroprevalance in asymptomatic horses. Epidemiol Infect, 137, 1163-1168.

17. Swayne DE., Beck JR., Smith CS., Shieh WJ., Zaki SR., 2001. Fatal encephalitis and myocarditis in young domestic geese (Anser anser domesticus) caused by West Nile virus. Emerg Infect Dis, 7, 751-753.

18. Thomas-Bachli AL., Pearl DL., Berke O., Parmley EJ., Barker IK., 2017. A geographic study of West Nile virus in humans, dead corvids and mosquitoes in Ontario using spatial scan statistics with a survival time application. Zoonoses Public Health, 00, 1-9.

19. Toplu N., Oğuzoğlu TÇ., Ural K., Albayrak H., Ozan E., Ertürk A., Epikmen ET., 2015. West Nile virus infection in horses: Detection by immunohistochemistry, in situ hybridization, and ELISA. Vet Pathol, 52, 1073-1076.

20. Yazici Z., Albayrak H., Ozan E., Gumusova S., 2012. The first investigation of West Nile virus in horses using real time RT-PCR in Middle Black Sea Region in Turkey. J Arthropod-Borne Dis, 6, 151-155. 